Wells, A. K., and J. F. Kirkaldy, 1948. Outline of Historical Geology. London.

White, H. J. O., 1921. A short account of the geology of the Isle of Wight. Mem. Geol. Surv. Gr. Brit.

WoOLDRIDGE, S. W., and D. L. LiNTON, 1939. Structure, surface, and drainage in south-east England. Inst. Brit. Geographers, Publication No. 10.

Geology Department,

N. E. Butcher.

THE UNIVERSITY,

READING.

23rd June, 1963.

\title{
AGE RELATIONS OF CONNEMARA MIGMATITES AND GALWAY GRANITE
}

SiR,-In Leake and Leggo's interesting paper (Geol. Mag., 100, 194-204) the migmatites which form the northern and western border of the Galway granite are attributed to an episode of regional metamorphism long antedating the intrusion of the granite. I have suggested (Geol. Mag., 94 (1957), 452-464) that they are derived from the granite.

As Leake and Leggo's text-fig. 1 shows, the migmatites occur close to the granite and this is one reason why I have considered them related to it. However, the relationship is not simple. If it were there would be gradational contacts everywhere, highly potassic migmatites would always be most common close to the granite and basic rocks would become steadily more abundant farther away. I found (op. cit., p. 458) and Leake (Proc. Roy. Irish Acad., 59B (1958), 155-203), and Leggo (Geol. Mag., 100, p. 195) have confirmed that potassic migmatites occur in various parts of the border. In some places close to the granite and in others near the outer margin.

To account for the sporadic distribution of migmatised and relatively unaltered rocks in the migmatite belt I suggested (Geol. Mag., 94 (1957), p. 462) that there had been movements roughly parallel to the plane of the foliation in the belt during the rise of the granite which had brought migmatites, formed at a deep level, next to less altered basic rocks and had carried rocks formed in the inner part of the belt to the outer part. I had found it necessary to postulate these movements, either strike faults or folds or both, to provide an explanation of the narrowing of the outcrop of the migmatite belt across the Shannawon and Bunnagippaun faults.

An essential feature of my interpretation of the structure was that deeper parts of the granite were exposed in the east and higher parts in the west. In the deeper parts of the intrusion the contact is concordant and the higher parts cross-cutting. The material in the migmatites has everywhere been brought from depth.

Leake and Leggo have shown that the granite contact is just discordant in the Maam Cross-Screeb area where I had mapped it as concordant and they cite abundant evidence to show that the granite and its contained potash feldspars in that area are different from the migmatite and its contained potash feldspars. Both these facts are consistent with my hypotheses and the former, with other evidence cited in their paper, enables my picture of structural variation along the northern contact to be refined thus :-

1. Highest level, west of Bertraghboy Bay : Small granites cutting across gently dipping migmatites and basic rocks.

2. High level, west of Screeb :

Main Galway Granite intrusion, unfoliated, cuts across migmatites dipping moderately. 
3. Intermediate level, Screeb :

4. Deep level, north-east of L. Seecon :

Main Galway Granite intrusion, foliated, just cross-cutting. Dips in granite and migmatite steep.

Main Galway Granite intrusion, foliated, migmatitic, concordant. Dips in granite and migmatite steep.

It is with some diffidence that I comment on Leake and Leggo's section on "Age relationships elsewhere in Connemara " because I worked in Connemara for a short time about ten years ago while Dr. Leake and his colleagues and former colleagues have compiled between them many tens of man-years of work, few of the results of which are generally available. Radiometric age determinations will, of course, be of value in elucidating the age relations of the granite but it would be a mistake to assign too much weight to the single determination quoted, as the authors pointed out in the discussion of their paper (Giletti, Moorbath, and Lambert, 1961, p. 270). The occurrence of five granite types in the west and north-west of the main Galway granite is to be expected, on my hypothesis, since this area underlay the eroded roof and as I wrote (1957, p. 454) "other facies are common near the margin of the intrusion". The gravity work mentioned by Leake and Leggo sounds interesting but there must be difficulties in selecting a density for the inhomogeneous migmatite and as on my hypothesis the main granite would be about 5 miles down at Murvey, interpretation in detail might be difficult.

I am separated from my work in Connemara by a considerable distance and a considerable time, and I am not very strongly committed to my original views so that I look forward to reading further accounts of the detailed work of Dr. Leake and his colleagues. Perhaps, as in this case, the results may not prove as inconsistent with my interpretation as the authors think.

\author{
Geology Department, \\ U.W.I., \\ MONA, KingSTON 7, \\ JAMAICA. \\ 20 th August, 1963.
}

KeVIN BURKe. 